\title{
Board size, corporate regulations and firm valuation in an emerging market: a simultaneous equation approach
}

\author{
Collins G. Ntim ${ }^{\mathrm{a} *}$, Kwaku K. Opong ${ }^{\mathrm{b}}$ and Jo Danbolt ${ }^{\mathrm{c}}$
}

\author{
Department of Accountancy and Finance ${ }^{\mathrm{a}}$ \\ University of Huddersfield Business School \\ University of Huddersfield \\ Huddersfield, UK
}

Accounting and Finance ${ }^{\mathrm{b}}$

Adam Smith Business School

University of Glasgow

Glasgow, UK

Accounting and Finance ${ }^{c}$

Edinburgh Business School

University of Edinburgh

Edinburgh, UK

${ }^{*}$ Corresponding author. Address for correspondence: Financial Ethics and Governance Research Group, Department of Accountancy and Finance, The Business School, University of Huddersfield, Queensgate Campus, Queensgate, Huddersfield, HD1 3DH, UK. Tel: +44 (0) 148447 1038. Fax: +44 (0) 148447 3148. E-mail: c.ntim@ hud.ac.uk. 


\title{
Board size, corporate regulations and firm valuation in an emerging market: a simultaneous equation approach
}

\begin{abstract}
We investigate the association between board size and firm valuation for a sample of 169 firms from 2002 to 2011 in South Africa (SA). The SA corporate context is interestingly and uniquely characterised by greater urgency to meet affirmative action regulations, such as black empowerment in board appointments, limited qualified and experienced directors, especially black directors, concentrated ownership, weak enforcement of corporate regulations and greater government ownership. These features make SA corporate boards perform a weaker agency (advisory, monitoring and disciplining) role than Western European and US boards, but a stronger resource dependence role, by providing access to resources, such as business contacts and contracts. This suggests that any positive impact of board size on firm valuation is likely to depend on the effective execution of the resource dependence role than the agency role. Our results suggest that board size has a positive association with firm valuation, consistent with larger boards providing better access to resources. Overall, our results support the resource dependence role of boards than their agency role. The results are robust across a raft of econometric models that control for different types of endogeneity, as well as different types of accounting and market-based firm valuation measures.
\end{abstract}

Keywords: Corporate governance, board regulations, firm valuation, simultaneous equations, South Africa

JEL Classification: G32, G34, G38 


\section{Introduction}

In this paper, we investigate the association between board size and firm valuation for South African (SA) firms. The continuing intense public (Walker Review, 2009; Freeman and Lindsay, 2012; Lin and Liu, 2012) and academic (Beiner et al., 2004; Siougle, 2007; Guest, 2009; Pant and Pattanayak, 2010; Chen and AlNajjar, 2012; Rivas, 2012) debate on board structures bears testimony to the view that corporate board size may affect firm valuation. Indeed, there is a theoretical consensus that corporate boards play an important role in the governance of corporations (Lipton and Lorsch, 1992; Jensen, 1993; Ntim, 2014). In contrast, the empirical literature (reviewed below) on the association between board size and firm valuation is mixed, even though a good number reports that larger boards negatively affect firm valuation. A number of critical issues, however, have been raised with regard to the results of prior studies. First, prior studies have been heavily criticised for apparent methodological deficiencies. Specifically, past studies have been criticised for not sufficiently controlling for endogeneity problems (Guest, 2009; Larcker and Rusticus, 2010), as well as for not accounting for any potential interdependencies between board size and other possible alternative corporate governance (CG) mechanisms (Agrawal and Knoeber, 1996; Beiner et al., 2004, 2006; Ntim et al., 2012a, b, 2013, 2014). Second, Guest (2009) suggests that the impact of board size on firm value may not just differ by firm-level features, but also by country-specific CG, institutional and legal differences. Yet, existing studies are heavily concentrated in the developed markets of Western Europe and US, which depict relatively similar institutional settings (Yermack, 1996; Conyon and Peck, 1998; Cheng, 2008).

Unsurprisingly, most of the negative relationship identified between board size and firm valuation has been attributed to agency theory, which indicates that larger boards tend to be associated with poor communication, monitoring and decision-making (Jensen, 1993; Yermack, 1996; Guest, 2009). However, corporate boards do not only advise, monitor and discipline management (agency role) (Lipton and Lorsch, 1992; Jensen, 1993; Chen and Yu, 2012), but also offer critical services and resource support (resource dependence role) (Pfeffer, 1973; Kiel and Nicholson, 2003). Arguably, in emerging markets with different institutional contexts, legal and CG structures (as discussed further below), the roles of corporate boards may differ, and consequently the association between board size and firm valuation can be expected to be different from what has been reported in developed markets. In fact, prior research suggests, for example, that corporate boards in emerging markets generally perform a weaker monitoring role (Okeahalam, 2004; Kumar, 2006; Henry, 2008; Al-Najjar, 2011, 2013). As such, an investigation of the link between board size and firm 
valuation in emerging markets, where there is a conspicuous dearth of empirical evidence (Mangena et al., 2012; Ntim et al., 2012a, b), is crucial in providing a more complete understanding of the impact of board size on firm valuation.

In this paper, we examine the association between board size and firm valuation for SA firms. SA is a particularly interesting emerging market to analyse. Historically, SA has an Anglo-American CG model, which implies that firms are free to choose their board members. However, post-Apartheid CG reforms, noticeably the 2002 King Report (hereafter King II) require SA firms to formally comply with a number of affirmative action CG regulations on black empowerment and employment equity, when appointing board members (Ntim and Soobaroyen, 2013a, b). These provisions generally seek to eliminate all forms of past discriminatory employment practices, but specifically aspire to significantly increase the participation of nonwhites (especially blacks) in senior management of important SA corporations, as part of the overall objective of addressing historical socio-economic inequalities between white and non-white South Africans.

Crucially, and unlike most Western European countries and the US, the SA government holds significant ownership stakes in public and private companies through the Public Investment Commission (PIC). ${ }^{1}$ This is an important feature because significant government ownership not only affects board size (Beiner et al., 2004; Chen et al., 2010), but also the ability of firms to reduce environmental uncertainties and secure critical resources (Pfeffer, 1973; Kiel and Nicholson, 2003), such as profitable government contracts to improve long term market value. Finally, prior research suggests that ownership of SA listed firms is relatively concentrated (Barr et al., 1995), which may make board appointments different from those of developed settings. We argue that the rich research context in terms of differences with developed countries, in addition to the acute lack of prior studies offer a compelling basis to investigate the link between board size and firm valuation in SA.

This paper makes a number of distinctive contributions to the extant literature. First, using a sample of 169 SA listed firms from 2002 to 2011, we provide evidence for the first time on the connection between board size and firm valuation in SA. This also contributes to the predominantly developed markets-based literature (mainly in Western Europe and US) on the association between board size and firm valuation. Second, we apply econometric models that adequately control for different types of endogeneity, including firm-level fixed effects and simultaneity. Distinctively, we respond to methodological criticisms of prior studies by introducing alternative CG mechanisms, including the percentage of non-executive directors, leverage, institutional and block ownerships that we have data on in addition to board size. This allows us to 
uniquely examine the level of interdependencies among the alternative CG mechanisms, as well as between firm valuation and the governance mechanisms.

In contrast to the evidence of the majority of the prior Western European and US studies, our results show a statistically significant and positive association between board size and firm valuation, as proxied by Tobin's Q. This implies that SA listed firms with larger boards tend to be associated with higher market valuation. The findings are consistent across a raft of econometric models that control for different types of endogeneity, as well as different types of accounting and market-based firm valuation measures. Our results offer empirical support to the resource dependence role of boards, but less to their agency role. We argue that in an emerging market that is characterised by comparatively weak CG structures, concentrated ownership, and greater central government ownership stakes in firms, as well as the need to meet affirmative action laws, such as black empowerment in board appointments, the board's role in securing critical resources to improve long-term market value appears to be more important than its ability to effectively perform the agency role.

The remainder of the paper is organised as follows. Section 2 reviews the prior literature on board size and firm valuation. Section 3 provides an overview of corporate board size regulations and firm valuation within the South African CG environment. Section 4 describes the data and research methodology. Section 5 reports empirical results. Section 6 presents robustness analyses, while section 7 concludes.

\section{Prior literature on board size and firm valuation}

Corporate boards of directors perform critical roles, and as such are considered to be an important governance mechanism (Lipton and Lorsch, 1992; Jensen, 1993). Generally, corporate boards perform two broad roles: agency and resource dependence (Kiel and Nicholson, 2003; Ntim et al., 2012a, b). First, agency theory (Jensen and Meckling, 1976; Al-Najjar, 2011, 2013) suggests that corporate boards advise (expert advice), supervise (monitor) and seek accountability (discipline) from management to ensure that managers pursue the interests of shareholders. Second, resource dependence theory (Pfeffer, 1973; Kiel and Nicholson, 2003) indicates that corporate boards help to link their firms' to the external environment, which reduces uncertainties and also facilitates securing critical resources, such as finance, information and reputation.

One view articulated by Guest (2009) is that larger boards are better placed to effectively perform both the agency and resource dependence roles than smaller ones. First, larger boards tend to have a greater number of outside or non-executive directors (NEDs), who are more independent and better placed to effectively advise, monitor and discipline management (Jensen 1993). Second, larger boards are associated 
with diversity in experience, ideas and skills, as well as greater opportunity to secure critical resources, including business contacts and contracts (Kiel and Nicholson, 2003; Ntim et al., 2012a, b).

A contrary and dominant theoretical view discussed by Jensen (1993) is that smaller boards may possibly be better for firm valuation. First, larger boards generally consume more pecuniary and non-pecuniary resources in the form of remuneration and perquisites than smaller boards (Jensen and Meckling, 1976). Second, Jensen (1993) argues that when a board gets too big, it not only becomes difficult to coordinate and communicate, but also comparatively easier to control by a dominant CEO due to associated increased director shirking and free-riding. Specifically, Lipton and Lorsch (1992) and Jensen (1993) suggest that there is an optimal board size, and board size should preferably fall between seven and nine directors. They argue that as board size exceeds ten directors, the additional costs of having larger boards typically associated with less cohesiveness, frank discussions and slow decision-making are higher than any marginal gains from intense monitoring of management activities. Limiting board size may, therefore, improve efficiency and increase firm value. Of critical note, however, is that much of the disadvantages of having larger boards have been attributed mainly to the probable ineffective execution of the agency role. It is still unclear within the extant literature as to whether larger boards also result in poor performance of the resource dependence role. However, prior studies do indicate that diversity in ideas, skills and critical resources, such as finance and information, increase with board size (Pfeffer, 1973; Kiel and Nicholson, 2003). This implies that it is highly likely that larger boards may not necessarily lead to poor execution of the resource dependence role.

The empirical literature is not only conflicting, but also disproportionately Western Europe and US based (Yermack, 1996; Conyon and Peck, 1998; Guest, 2009), with the majority reporting a negative link between board size and firm valuation. Yermack (1996) and Eisenberg et al. (1998) are among the pioneers to investigate the association between board size and firm valuation. Yermack's sample consisted of 452 large US companies (with average board size of 12.3 members) from 1984 to 1991, while Eisenberg et al.'s sample included 879 small and medium size Finnish firms (with a mean board size of 3.7 members) from 1992 to 1994. Despite the substantial differences in board size, both studies report a negative relationship between board size and firm valuation proxies, such as Tobin's Q and return on assets (ROA). Their results also contradict Lipton and Lorsch's (1992) and Jensen's (1993) optimal board size proposition. The results of other Western European (Conyon and Peck, 1998; Beiner et al., 2004; Lasfer, 2004; Guest, 2009) and US (Vefeas, 1999; Cheng, 2008; Cheng et al., 2008) studies are largely consistent with those of Yermack and 
Eisenberg et al. Adams and Mehran (2005) and Beiner et al. (2006) are the only conspicuous exceptions, with both studies reporting a positive relationship between board size and Tobin's Q, using a sample of US (35 banks) and Swiss (109 companies) listed firms, respectively.

The results of the few non Western Europe and US studies, however, are less consistent, and thus offer support to the suggestions of Guest (2009) that the board size and firm valuation link may be influenced both by firm and country level characteristics. For example, using samples of Australian listed firms, Kiel and Nicholson (2003) and Henry (2008) report a positive link between board size and firm valuation, as measured by ROA and Tobin's Q, respectively. In contrast, Mak and Kusnadi (2005) provide evidence of a negative association between board size and Tobin's Q in samples of Malaysian listed firms. Bozec (2005) also finds a negative link between board size and return on sales for a sample of 25 large Canadian firms.

Of close interest, but largely due to relative lack of data, is that there is a general dearth of evidence on the association between board size and firm valuation in Africa and SA in particular (Okeahalam, 2004; Ntim et al., 2012a, b). However, we argue that the paucity of empirical evidence on South Africa also offers genuine opportunities to make distinct contributions to the extant literature. Sanda et al. (2010) and Mangena et al. (2012) are rare exceptions. In contrast to the results of studies conducted in developed countries, both studies report positive association between board size and firm valuation, as proxied by ROA and Tobin's Q, in samples of 72 Zimbabwean and 93 Nigerian listed firms, respectively. A further issue of major concern is that despite the evidence that endogeneity can affect empirical results (Larcker and Rusticus, 2010), most of the prior studies do not sufficiently control for endogeneity (Beiner et al., 2004, 2006; Guest, 2009). Specifically, most of the prior studies have been criticised for not accounting for possible interrelationships between board size and potential alternative CG mechanisms (Beiner et al., 2004, 2006; Chen and Al-Najjar, 2012). Agrawal and Knoeber (1996) suggest that the existence of alternative CG mechanisms means that the valuation effects of some CG structures may possibly depend on their interrelations with other CG mechanisms. This implies that a regression of firm value on a single CG mechanism may lead to misleading results.

Our study differs from prior studies in a number of ways. First, our sample consists of 169 SA listed firms from 2002 to 2011. This allows us to provide for the first time evidence on the association between board size and firm value with respect to SA, and also contributes to the predominantly Western Europe and US based literature. Second, we apply econometric models that adequately control for different types of 
endogeneity, including fixed effects and simultaneity. Distinctively, we respond to criticisms of prior studies by introducing four alternative CG mechanisms that we have data on in our analysis to investigate the level of interdependencies among the alternative CG mechanisms, as well as between firm valuation and the five governance mechanisms.

\section{Corporate board size regulations and firm valuation within the South African CG environment}

Guest (2009) argues that the functions of corporate boards may possibly differ by country, and as such the board size and firm value association may not merely vary by firm-level features, but also by country specific characteristics. For example, the potential value maximising or minimising effects of larger boards will depend on their specific roles and effectiveness, but this may arguably differ according to the broader CG framework, institutional setting, cultural and legal environment. In this regard, whereas most of the prescribed duties of corporate boards in SA are similar to those of the UK and US, for example, a number of contextual factors suggest that the agency (advising, monitoring and disciplining) role may be poorly carried out in SA compared with the resource (such as finance, business contacts and contracts) dependence role.

First, board appointments in post-Apartheid SA are greatly influenced by the need to meet affirmative action CG provisions, including black empowerment and employment equity ${ }^{2}$ (King Report, 2002). Furthermore, there is a relative shortage of qualified and experienced directors in SA, especially non-white or black directors (King Committee, 1994). The need to meet affirmative action targets, especially black empowerment in an environment of limited qualified and experienced directors implies that SA boards are likely to be large, but may not necessarily have the required expertise to effectively perform the agency (monitoring) role. By contrast, larger boards may not only have more 'well-connected and influential' members, especially those with close links to the ruling African National Congress ${ }^{3}$, but also be better placed to meet affirmative action CG provisions (Malherbe and Segal, 2003; Ntim and Soobaroyen, 2013a, b). However, meeting black empowerment and employment equity targets, for example, is a major way by which SA firms can gain access to critical resources, including securing and renewing profitable government and mining contracts (Murray, 2000; Ntim and Soobaroyen, 2013a, b). Larger SA boards may, therefore, be able to effectively perform the resource dependence role.

Second, there is significant central government ownership with greater influence in director appointments in SA companies (PIC Annual Report, 2009). This can weaken board independence (Beiner et al., 2004, 2006), and thus the ability to effectively advise and discipline management. Third, SA firms have 
concentrated ownership (Barr et al., 1995). This implies that the market for corporate and managerial control may be less active, and hence directors may be less motivated to effectively monitor management. Fourth, SA firms have greater institutional ownership, but weaker shareholder activism (Malherbe and Segal, 2003). This further weakens SA boards' ability to effectively execute the monitoring role. Finally, SA has a relatively weak record of implementing and enforcing corporate regulations (King Committee, 2002). Malherbe and Segal (2003) indicate, for example, that unlike the US, SA directors are rarely prosecuted for not properly performing their fiduciary duties, and as such they consider their main duty to be to secure critical resources for their firms rather than to effectively monitor management. In sum, the uniqueness of the SA corporate setting suggests that the association between board size and firm value can be expected to be different from those reported for developed countries. We, therefore, seek to empirically investigate the association between board size and firm value within this arguably interesting research context.

\section{Data and research methodology}

\subsection{Data: sample selection, sources, and description}

Our sample is based on all the 291 non-financial ${ }^{4}$ firms listed on the JSE Ltd as at 31/12/2011. We use CG and financial variables to examine the association between board size and firm valuation. The CG variables

were collected from the sampled firms' annual reports. We downloaded the annual reports from the Perfect Information Database, while the financial data were collected from DataStream. The firms in our final sample had to meet two criteria: the availability of a firm's complete nine-year annual reports from 2002 to 2010 inclusive, and the availability of a firm's corresponding financial data from 2003 to 2011 inclusive. $^{5}$ The criteria were set for several reasons. First, and following prior studies (Yermack, 1996; Conyon and Peck, 1998), the criteria ensured that the requirements for a balanced panel data analysis were met. There are advantages for using panel data, including having both time series and cross-sectional observations, more degrees of freedom and less collinearity among variables (Gujarati, 2003). Second, analysis of nine-year data with both cross-sectional and time series properties may help in determining whether the observed crosssectional association between board size and firm valuation also holds over time. This can facilitate direct comparisons to be drawn with the results of past studies (Yermack, 1996; Guest, 2009). The complete data required is obtained for a total of 169 out of the $291^{6}$ firms over nine firm-years (a total of 1,521 firm-year observations) from 8 industries for our regression analysis. A potential limitation is that it may introduce 
survivorship bias into the sample selection process. However, the criteria still generated a much larger sample size than what has been used in prior SA studies (Mangena and Chamisa, 2008). Arguably, generalisability of the research findings has not been affected by our sample selection criteria. ${ }^{7}$

\subsection{Research methodology: definition of variables and model specification}

The main independent variable in our regression analysis is board size and note that Table 1 fully defines all variables used in this study were operationalised. As previously discussed, SA boards naturally perform a weaker monitoring role. Arguably, monitoring effectiveness is less likely to depend on board size. In contrast, SA boards can be expected to perform a stronger resource dependence role. Thus, it can be expected that any positive association between board size and firm valuation will depend on the effectiveness with which the resource dependence role is executed. In fact, the limited past African and other emerging markets studies suggest that board size impact positively on firm valuation (Henry, 2008; Sanda et al., 2010). Therefore, we hypothesise that board size will be positively related to firm valuation. Tobin's $\mathrm{Q}(Q)$ is our key measure of market valuation, but, as a robustness check, we also employ return on assets (ROA) and Total share return $(T S R)$ as alternative accounting and market-based performance measures, respectively. It measures the market's valuation of the quality of a firm's CG mechanisms, with a higher $Q$ indicating greater effectiveness of a firm's CG mechanisms (Chung and Pruitt, 1994). Following prior studies (Yermack, 1996; Guest, 2009), we include below a number of control (exogenous) variables.

Insert Table 1 about here

First, companies with greater investment opportunities experience faster growth (Henry, 2008), and are likely to be associated with higher valuation. Thus, following Beiner et al. $(2004,2006)$, we predict a positive link between $Q$ and growth opportunities $(G R O W T H)$, as measured by annual sales growth. Second, competitive advantage can be gained by companies that invest more in research and development (Cheng et al., 2008; Al-Najjar, 2011, 2013), and as such may have higher $Q$. In contrast, research and development require greater capital investment (Vefeas, 1999; Welch et al., 2002), and thus may relate negatively to current $Q$. Similarly, greater debt usage can increase performance by preventing opportunistic managers from expropriating 'free cash flows' (Jensen, 1986; Al-Najjar, 2011, 2013). By contrast, higher levels of gearing can lead to financial distress, and reduce the capacity to exploit growth opportunities (Jensen, 1986). Also, due to greater agency problems, larger firms are likely to engage in good CG practices (Beiner et al., 2006), and may have higher $Q$. By contrast, smaller firms tend to have higher growth opportunities (Mangena et al., 
2012; Al-Najjar, 2011, 2013), and may be related to higher $Q$. Given the mixed evidence, we hypothesise that gearing $(G E A R)$, capital expenditure $(C A P E X)$ and firm size $(L N T A)$ will correlate either positively or negatively with firm valuation.

Third, firms that cross-list to overseas stock exchanges are likely to be exposed to greater funding and investment opportunities, and may have higher $Q$ (Ntim et al., 2012a, b). Hence, we predict that cross-listing (CROSLIST) will be positively related to $Q$. Fourth, audit firm size is positively related to auditor independence and audit quality (DeAngelo, 1981), and as such firms audited by big and prestigious audit firms may have higher $Q$. Hence, we expect audit firm size to correlate positively with $Q$. Fifth, government ownership can influence board appointments and weaken board independence (Beiner et al., 2004, 2006), but may be associated with access to critical resources, such as finance and profitable government contracts (Murray, 2000). Thus, we predict a positive association between government ownership (GOVOWN) and $Q$. Finally, following Henry (2008) and Guest (2009), we hypothesise that $Q$ will vary across different industries and financial years. Hence, we include industry dummies for the five remaining industries: basic materials and oil \& gas; consumer goods; consumer services and health care; industrials; and technology \& telecommunications, and year dummies for the financial years 2003 to 2011. Assuming that all relations are linear, our main OLS regression equation to be estimated is:

$$
Q_{t}=\alpha_{0}+\beta_{1} \text { BSIZE }_{i t-1}+\sum_{i=1}^{n} \beta_{i} \operatorname{CONTROLS}_{i t-1}+\varepsilon_{i t-1}
$$

where: $Q$ refers to Tobin's Q; BSIZE is board size; CONTROLS refers to the control variables for growth (GROWTH), capital expenditure (CAPEX), gearing (GEAR), firm size (LNTA), cross-listing (CROSLIST), audit firm size (BIG4), government ownership (GOVOWN), industry (INDUST)and year dummies (YD).

\subsection{Two-stage least squares, alternative CG mechanisms and possible interdependencies}

Agrawal and Knoeber (1996) suggest that the existence of alternative CG mechanisms implies that the use of one mechanism may possibly depend on the use of others to be effective. As such, OLS regressions of $Q$ on a single CG mechanism as specified in (1), for example, can result in endogenous associations (Beiner et al., 2004, 2006). We address this methodological criticism of prior studies by introducing four alternative CG structures that we have data on in addition to our BSIZE and $Q$ to develop a system of six simultaneous equations. The four alternative CG structures are the percentage of non-executive directors (NEDs), leverage $(L E V)$, block $(B L K O W N)$, and institutional (INSOWN) ownerships. We then estimate the six equations using 
two-stage least squares $(2 S L S)$ to examine the relationship between the CG mechanisms and $Q$. The $2 S L S$ analysis involves two stages. In the first stage, we estimate each of equations (2) to (6) specified below. We save the resulting predicted values (i.e., predicted part of each CG mechanism). In the second stage, we use the predicted parts as instruments for the CG mechanisms. Finally, we estimate equation (7) specified below along with the control variables and their respective instrument using the $2 S L S$ technique. The rationale is that where one mechanism is used less, others may be used more, resulting in similar valuation outcomes (Agrawal \& Knoeber, 1996). The percentage of $N E D s$, for example, may be positively related to BSIZE. Thus, it may be the case that any board size valuation effect may depend on how the board is composed, and possibly on the other CG mechanisms (Beiner et al., 2004, 2006). We describe how our system of six equations is developed for each dependent variable.

\subsubsection{Board size}

We assume that BSIZE depends on the choices of the other four alternative CG mechanisms (NEDs, LEV, $B L K O W N$, and INSOWN), firm valuation $(Q)$ and the exogenous variables. Larger firms have bigger boards and complex issues to address (Beiner et al. 2004, 2006), and as such we predict that firm size (LNTA), audit firm size (BIG4) and cross-listing (CROSLIST) will be positively related to BSIZE. Larger firms have lower growth and investment opportunities (Agrawal \& Knoeber, 1996), and thus we expect sales growth $(G R O W T H)$ and capital expenditure $(C A P E X)$ to correlate negatively with BSIZE. As larger firms are subjected to greater media and public scrutiny (Ntim et al., 2012a, b), we hypothesise that BSIZE will be positively associated with government ownership $(G O V O W N)$, the presence of a CG committee $(C G C O M)$ and gearing $(G E A R)$. We also expect BSIZE to vary across different industries (INDUST) and financial years $(Y D)$. Labelling all ten exogenous variables simply as EXOGENOUS, the first equation in the system to be estimated is specified as:

$$
\begin{aligned}
& B S I Z E_{i t}=\alpha_{0}+\beta_{1} N E D s_{i t}+\beta_{2} L E V_{i t}+\beta_{3} B L K O W N_{i t} \\
& +\beta_{4} I N S O W N_{i t}+\beta_{5} Q_{i t}+\sum_{i=1}^{n} \beta_{i} \text { EXOGENOUS }_{t}+\varepsilon_{i t}
\end{aligned}
$$

\subsubsection{Percentage of non-executive directors}

A higher percentage of non-executive directors (NEDs) can increase monitoring and offer greater opportunities to secure critical resources to improve firm value (Kiel and Nicholson, 2003). King II encourages SA boards to have a majority of $N E D s$ and hence, the second dependent variable in the system of 
equations is the percentage of NEDs. Larger firms have greater visibility and are more attractive to prospective directors (Agrawal and Knoeber, 1996; Beiner et al., 2006), and as such it is hypothesised that NEDs will be positively related to firm size (LNTA), audit firm size (BIG4), cross-listing (CROSLIST), gearing $(G E A R)$, government ownership $(G O V O W N)$ and the presence of a CG committee $(C G C O M)$. We predict that sales growth $(G R O W T H)$ and capital expenditure $(C A P E X)$ will correlate negatively with $N E D s$, as smaller companies have better growth and investment prospects (Agrawal and Knoeber, 1996; Ntim et al., 2012a, b). We also expect NEDs to vary across different industries (INDUST) and over-time (YD). Naming all ten exogenous variables simply as EXOGENOUS, the second equation to be estimated in the system is specified as:

$$
\begin{aligned}
\text { NEDS }_{i t}=\alpha_{0}+ & \beta_{1} \text { BSIZE }_{i t}+\beta_{2} \text { LEV }_{i t}+\beta_{3} \text { BLKOWN }_{i t} \\
& +\beta_{4} \text { INSOWN }_{i t}+\beta_{5} Q_{i t}+\sum_{i=1}^{n} \beta_{i} \text { EXOGENOUS }_{t t}+\varepsilon_{i t}
\end{aligned}
$$

\subsubsection{Leverage}

Greater debt usage can minimise managerial expropriation of 'free cash flows' (Jensen, 1986; Al-Najjar, 2011, 2013). Hence, leverage ( $L E V)$ is the third dependent variable in our system. Bevan and Danbolt (2004) report that debt usage is positively related to size, but negatively linked to profitability. Thus, we expect $L E V$ to correlate positively with firm size $(L N T A)$, but to be negatively related to $Q$. Also, greater debt usage increases financial stress and reduces the ability to exploit growth and investment opportunities (Jensen, 1986; Bevan and Danbolt, 2004). Hence, we predict that growth (GROWTH) and investment (CAPEX) potential will relate negatively to $L E V$. We expect debt usage to vary across different industries (INDUST) and over time $(Y D)$. Labelling all five exogenous variables simply as EXOGENOUS, the third equation in the system to be estimated is specified as:

$$
\begin{aligned}
L E V_{i t}=\alpha_{0}+ & \beta_{1} \text { BSIZE }_{i t}+\beta_{2} L E V_{i t}+\beta_{3} B L K O W N_{i t} \\
& +\beta_{4} \operatorname{INSOWN}_{i t}+\beta_{5} Q_{i t}+\sum_{i=1}^{n} \beta_{i} E X O G E N O U S_{i t}+\varepsilon_{i t}
\end{aligned}
$$

\subsubsection{Block ownership}

Block ownership can increase monitoring, reduce agency costs and improve firm value (Jensen and Meckling, 1976). By contrast, block owners can connive with managers to expropriate company resources at the expense of minority shareholders (Ntim et al., 2012a, b). Thus, block ownership $(B L K O W N)$ is the fourth dependent variable in our system of equations. We expect a negative link between $B L K O W N$ and firm size (LNTA), as it 
costs more to buy a portion of a larger firm (Beiner et al., 2006). It is attractive to buy shares in larger firms with better growth and investment opportunities (Agrawal and Knoeber 1996; Beiner et al., 2004), and as such we predict that growth $(G R O W T H)$ and investment $(C A P E X)$ potential will correlate negatively with BLKOWN. Also, firms with BLKOWN tend to use less debt (Beiner et al., 2004, 2006; Ntim et al., 2012a, b), and so gearing $(G E A R)$ is expected to correlate negatively with $B L K O W N$. We also expect $B L K O W N$ to differ across different industries (INDUST) and over time $(Y D)$. Referring to all six exogenous variables simply as EXOGENOUS, the fourth equation to be estimated in the system is specified as:

$$
\begin{aligned}
\operatorname{BLKOWN}_{i t}=\alpha_{0} & +\beta_{1} \text { BSIZE }_{i t}+\beta_{2} \text { NEDs }_{i t}+\beta_{3} \text { LEV }_{i t} \\
& +\beta_{4} \operatorname{INSOWN}_{i t}+\beta_{5} Q_{i t}+\sum_{i=1}^{n} \beta_{i} \text { EXOGENOUS }_{t t}+\varepsilon_{i t}
\end{aligned}
$$

\subsubsection{Institutional ownership}

Institutional shareholders have greater financial strength, and as such can positively affect CG mechanisms and firm value (Barr et al., 1995; Mukherjee and Roy, 2011). King II also urges institutional shareholders to play active roles in setting executive pay in SA firms and hence, the dependent variable in the sixth equation of the system is institutional ownership (INSOWN). Beiner et al. (2006) suggest that it is more profitable to hold shares in firms with better growth and investment opportunities, and thus sales growth $(G R O W T H)$ and capital expenditure $(C A P E X)$ are hypothesised to relate positively to INSOWN. Larger firms are attractive to institutions (Agrawal and Knoeber, 1996) and therefore, INSOWN is expected to be positively associated with firm size $(L N T A)$, government ownership $(G O V O W N)$ and the presence of a CG committee $(C G C O M)$. We also expect INSOWN to vary across different industries (INDUST) and over time (YD). Calling all seven exogenous variables simply as EXOGENOUS, the fifth equation to be estimated in the system is specified as:

$$
\begin{aligned}
\operatorname{INSOWN}_{i t}=\alpha_{0} & +\beta_{1} \text { BSIZE }_{i t}+\beta_{2} N E D s_{i t}+\beta_{3} L E V_{i t} \\
& +\beta_{4} \text { BLKOWN }_{i t}+\beta_{5} Q_{i t}+\sum_{i=1}^{n} \beta_{i} \text { EXOGENOUS }_{i t}+\varepsilon_{i t}
\end{aligned}
$$

\subsubsection{The relationship between firm value $(Q)$ and $C G$ mechanisms}

To investigate the link between $Q$ and the 5 CG mechanisms, $Q$ is the dependent variable in the last equation in our system. All the control variables included in equation (1) are named simply as CONTROLS. Hence, the final equation to be estimated in the system is specified as: 


$$
\begin{aligned}
Q_{i t}=\alpha_{0}+ & \beta_{1} \text { BSIZE }_{i t-1}+\beta_{2} \text { NEDS }_{i t-1}+\beta_{3} \text { LEV }_{i t-1}+\beta_{4} \text { BLKOWN }_{i t-1} \\
& +\beta_{5} \text { INSOWN }_{i t-1}+\sum_{i=1}^{n} \beta_{i} \text { CONTROLS }_{i t-1}+\varepsilon_{i t-1}
\end{aligned}
$$

\section{Empirical results and discussion}

\subsection{Empirical results: descriptive statistics and univariate regression analysis}

Table 2 contains descriptive statistics of all variables included in our analysis. For brevity, we avoid a detailed discussion, but generally all the variables show wide variations. Table 2 indicates, for example, that $Q$ ranges from a minimum of 0.72 to a maximum of 3.60 , with an average of 1.56 . Similar to past studies (Beiner et al., 2006; Guest, 2009), BSIZE is between 4 and 18, with a median of 10 board members. Our alternative firm valuation proxies (ROA and TSR) and CG mechanisms (NEDs, LEV, BLKOWN, and INSOWN), as well as the exogenous variables, indicate wide variations. This implies that our sample has been adequately selected to achieve sufficient variation, and thus reduces the possibilities of sample selection bias.

\section{Insert Table 2 about here}

We initially test all our hypotheses by applying the OLS regression technique. Hence, OLS assumptions of multicollinearity, autocorrelation, normality, homoscedasticity and linearity are tested. Table 3 presents the correlation matrix for all variables included in our analysis to test for multicollinearity. For robust results, both the Pearson's parametric and Spearman's non-parametric coefficients are reported. We note that both the magnitude and direction of the parametric and non-parametric correlation coefficients are very similar, suggesting that no serious non-normality problems exist. Additionally, correlations among the variables are shown to be fairly low, indicating that there are no major multicollinearity problems in the variables. We further examined (for brevity not reported here, but available upon request) scatter plots for $P-P$ and $Q-Q$, studentised residuals, Cook's distances and Durbin-Watson statistics. The tests indicated no serious violation of the OLS assumptions of homoscedasticity, linearity, normality and autocorrelation, respectively.

Insert Table 3 about here

Table 3 also indicates statistically significant associations among the CG structures, and also between $Q$ and the CG mechanisms. Of special interest, BSIZE is positively related to $Q$, implying that SA firms with larger boards have higher valuation, and thus offering support to the resource dependence hypothesis. Indeed, GOVOWN correlates positively with both $Q$ and BSIZE. This suggests that GOVOWN appears to offer access

to critical resources, but associated political influence in board appointments invariably results in a larger 
board. With respect to the four alternative CG mechanisms, NEDs and INSOWN are positively related to $B S I Z E$ and $Q$, whilst $B L K O W N$ and $L E V$ correlate negatively with $B S I Z E$ and $Q$. However, while firms with greater $L E V$ receive lower valuation (coefficient is negative and significant), those with $B L K O W N$ are not necessarily valued less highly (coefficient is negative, but not significant). Finally, there are statistically significant correlations between $Q$ and the control variables. For example, CAPEX and GEAR are significant and negatively related to $Q$, while $L N T A, G R O W T H, G O V O W N, B I G 4$ and CROSLIST are significant and positively related to $Q$, as predicted.

\subsection{Empirical results: OLS (multivariate) regression analysis}

Table 4 presents OLS regression results of $Q$ on BSIZE. Column 3 of Table 4 reports the results of regressing $Q$ on $B S I Z E$ alone, whereas columns 4 to 9 report the results of regressing $Q$ on $B S I Z E$ and the control variables for the pooled ${ }^{8}$ sample and for each other firm-year, respectively. As predicted, and reported in Column 3 of Table 4, the coefficient of BSIZE is positive (0.104) and statistically significant at the $1 \%$ level. However, the coefficient on the constant term for equation (1) reported in column 3 of Table 4 is statistically significant and appears to indicate that there may be omitted variables bias. Therefore, the control variables are included in the regressions and reported in columns 4 to 9 of Table 4 to account for potential omitted variables bias.

Insert Table 4 about here

Crucially, the coefficient on BSIZE remains statistically significant and positive over the entire sample period, implying that SA firms with larger boards tend to be associated with higher market valuation. The positive coefficient is consistent with our hypothesis that SA boards perform a stronger resource dependence role, but a weaker agency role, and that larger SA boards are better placed to attract critical resources, such as finance, business contacts and contracts to improve long-term firm value. Our evidence also offers support to the results of past African and other emerging markets studies (Henry, 2008; Mangena et al., 2012), but generally contradicts the findings of prior Western European and US studies (Yermack, 1996; Guest, 2009). Generally, the coefficients on the control variables in the lower part of Columns 4 of Table 4 are of the same sign as hypothesised. For instance, GOVOWN, BIG4 and CROSLIST are positive and significantly related to $Q$, while the coefficient on $L N T A$ is negative and significantly associated with $Q$ over the entire sample period, as predicted. Consistent with the results of Henry (2008), the coefficient on the year dummies are statistically significant. This indicates that $Q$ varies over time, but the insignificant coefficients on the industry dummies, 
except the consumer services firms, do not support the results of Sanda et al. (2010). Finally, the $F$-values in Table 4 consistently reject the null hypothesis that the coefficients on BSIZE and control variables are equal to zero. Similar to past studies (Beiner et al., 2006; Guest, 2009), the adjusted $R^{2}$ is between $3 \%$ and $41 \%$, implying that our seven regression models can explain some variations in our sampled firms' $Q$.

\section{Robustness analyses}

Our regression analysis so far does not take into consideration the presence of alternative CG structures, firm value proxies, estimation techniques and endogeneity. The positive relationship between $B S I Z E$ and $Q$, for example, could consequently be spurious. In this section, we examine how robust our results are to the existence of alternative CG mechanisms and endogenous (especially simultaneous endogeneity) associations, firm value proxies, as well as firm-level fixed effects.

\subsection{Results based on a two-stage least squares estimation of equations (2) To (7)}

Our analysis proceeds in two steps. First, we use OLS to estimate equation (7) as a single equation, which permits the availability of all the alternative CG mechanisms, but does not allow for simultaneous interdependencies to exist among them. The underlying notion is to determine what happens to BSIZE in the presence of alternative CG mechanisms. Noticeably, the results (for brevity not reported here, but available upon request) suggest that board size remains positive and significant at the $5 \%$ level in the presence of the other four CG mechanisms. Additionally, the coefficients on the NEDs and INSOWN are significant at the $10 \%$ level and positively related to $Q$, while $L E V$ and $B L K O W N$ are negative, but insignificantly associated with $Q$. The positive link between $B S I Z E$ and $Q$ supports the results of previous studies relating to Africa and other emerging markets (Kiel \& Nicholson, 2003; Sanda et al., 2010), but rejects the findings of past studies conducted in Western Europe and US (Vefeas, 1999; Lasfer, 2004).

Second, and following Agrawal and Knoeber (1996) and Beiner et al. (2004, 2006), we estimate equation (7) along with equations (2) to (6) as a system of simultaneous equations, using two-stage least squares $(2 S L S) .{ }^{9}$ Specifically, in the first stage, we estimate each of equations (2) to (6) specified above along with their respective control variables. We save the resulting predicted values (i.e., predicted part of each CG mechanism). In the second stage, we use the predicted parts as instruments for the CG mechanisms. ${ }^{10}$ Finally, we estimate equation (7) along with the control variables and their respective instruments using the $2 S L S$ technique. As previously explained, this procedure treats firm value $(Q)$ as endogenous along with the five 
CG mechanisms. Uniquely, this structure permits each of the five CG mechanisms to simultaneously affect all the others in order to detect complementary or substitution effects, but also allows $Q$ to affect the choice of each of the five CG mechanisms.

Table 5 reports the results of the two-stage estimation of equations (2) to (7). Of particular interest, the coefficient on BSIZE in Column 8 of Table 5 remains positive and significant at the 5\% level. This implies that our finding of a positive association between BSIZE and $Q$ is robust to simultaneous endogeneity and/or the introduction of alternative CG mechanisms into the analysis. The positive association between $Q$ and BSIZE again supports the results of prior African and other emerging markets studies (Henry, 2008; Sanda et al., 2010), but contradicts the findings of the majority of Western European and US studies (Conyon and Peck, 1998; Cheng, 2008). Our 2SLS results in Column 8 of Table 5 further indicate that the coefficients on the NEDS and INSOWN remain significant and positive. This implies that SA boards with higher NEDs and INSOWN have higher valuation. Perhaps, this is less surprising given that both correlate positively (see Table 3) with BSIZE and GOVOWN. In contrast, the coefficients on BLKOWN and $L E V$ are still negative, but leverage is now statistically significant. The significant negative link between $L E V$ and $Q$ does not support capital structure and Jensen's (1986) 'free cash flow' theories, but rather seems to suggest that financial distress associated with greater debt usage reduces the ability of SA firms to exploit growth opportunities.

Insert Table 5 about here

Additionally, the findings in Table 5 show significant interrelations among the 5 CG mechanisms and $Q$. First, our results in Column 3 show that the coefficient on $Q$ is positive and significant. This means that larger $B S I Z E$ is not only associated with higher firm valuation, but that there is a reverse association (i.e., SA firms with higher $Q$ values or successful SA firms also seem to attract more potential board members). Consistent with our prediction, Column 3 indicates further that higher NEDs and INSOWN are significantly associated with larger BSIZE, but greater $L E V$ usage and lesser $B L K O W N$ are not significantly related to larger BSIZE. This also implies that NEDs, INSOWN and BSIZE are complementary CG mechanisms. Second, our findings in Column 4 of Table 5 indicate that there is a significant reverse association among NEDs, BSIZE and $Q$. This further supports our conclusion that the two CG mechanisms are complements, as more outside directors will invariably results in a larger BSIZE. Third, the results in Column 5 of Table 5 show that BSIZE and $B L K O W N$ have a significant and positive association with $L E V$, implying that larger SA firms tend to use more debt. 
Fourth, our findings in Column 6 of Table 5 suggest that BLKOWN is significantly and positively related to $L E V$ and INSOWN. This means that there is a reverse complementary association between $L E V$ and $B L K O W N$, with $B L K O W N$ resulting in greater debt usage and vice-versa. This rejects our hypothesis that SA firms with significant $B L K O W N$ are likely to use less debt. Fifth, our results in Column 7 of Table 5 indicate that INSOWN is associated with a significantly larger BSIZE and greater BLKOWN. This is consistent with our hypothesis that due to their greater financial strength, institutional shareholders cannot only afford to buy a larger part of firms, but also are more likely to seek board representations, resulting in a larger $B L K O W N$. Finally, the coefficients on the exogenous variables in the lower part of Table 5 generally show the hypothesised signs. For example, Column 3 indicates that SA firms with larger BSIZE tend to have a CG committee, a big four auditor, be cross-listed, have larger size and significant GOVOWN. The coefficients on the exogenous variables under the percentage of NEDs, LEV, BLKOWN and INSOWN all show the predicted signs. Consistent with past studies (Beiner et al., 2006; Guest, 2009), the $F$-values in Table 5 always reject the null hypothesis that the coefficients on the independent variables are jointly equal to zero, with adjusted $R^{2}$ between $13 \%$ and $47 \%$.

\subsection{Alternative firm value proxies and firm-level fixed-effects}

As previously indicated, we do not know whether our findings are robust to alternative firm value proxies or other estimation techniques. In this final subsection, we conduct two further important robustness analyses. First, we examine how robust our results are to two alternative firm value proxies that we have data on: total share returns (TSR - a market based measure) and return on assets ( $R O A-$ an accounting based proxy). As previously explained, these firm value proxies have been used widely within the CG literature (Beiner et al., 2006; Guest, 2009), and as such are deemed to be appropriate. Just like $Q$, effective CG mechanisms are expected to be related to higher ROA and TSR. Table 6 contains regression results based on our alternative firm value measures and the estimation of a fixed effects model. Columns 3 and 4 report OLS regression results of $T S R$ on $B S I Z E$ without and with the control variables, respectively. Similar results for our $R O A$ proxy are contained in Columns 5 and 6 of Table 6, respectively. Our results show that the coefficients on BSIZE in Columns 3 to 6 remain positive and significant at the 1 or $5 \%$ level. This implies that our results are robust when a market (TSR) or an accounting $(R O A)$ based measure of firm value is used instead of $Q$.

Insert Table 6 about here 
Finally, firms tend to vary in their opportunities and difficulties that they face over time. This can result in a situation where $B S I Z E$ and firm valuation are jointly and dynamically determined by unobserved firmspecific variables (Henry, 2008; Guest, 2009), which simple OLS regressions may be unable to detect. Hence, given the panel nature of our data and following past studies (Henry, 2008; Guest, 2009), we estimate a fixed effects model to control for possible unobserved firm-level heterogeneity. This involves re-estimating equation (1), with the inclusion of 168 dummies to represent the 169 sampled firms. Our fixed effects results reported in Column 7 of Table 6 indicate that the coefficient on BSIZE remains positive and significant at the $1 \%$ level, implying that our findings are robust to potential unobserved firm-level heterogeneity. Overall, the results from our robustness analyses make us reasonably confident that our main finding of a positive relationship between $B S I Z E$ and firm value for SA firms is not spuriously driven by any form of endogeneity.

\section{Summary and conclusions}

In this paper, we have attempted to examine the association between board size and firm value in South Africa (SA). The SA corporate context is interestingly and uniquely characterised by greater urgency to meet affirmative action regulations, such as black empowerment in board appointments, limited qualified and experienced directors, especially black directors, concentrated ownership, weak enforcement of corporate regulations and greater government ownership. These characteristics make SA corporate boards to perform a weaker agency (advisory, monitoring and disciplining) role than Western European and US boards, but a stronger resource (resources, such as business contacts and contracts) dependence role. While a majority of the prior Western European and US literature suggests that smaller boards may better fulfil an effective governance role, we might expect a positive relationship between board size and firm value in the South African context, if larger boards better perform the resource dependence role.

Using a sample of 169 SA listed firms from 2002 to 2011, our main conclusion is that board size has a positive association with firm valuation, as proxied by Tobin's $Q(Q)$. This implies that SA firms with larger boards have higher valuation. Our main OLS results are robust across a raft of econometric models that control for different types of endogeneity, including simultaneity and firm-level fixed effects, as well as different types of accounting and market-based firm valuation measures, such as return on assets and total shareholder return. Our findings offer empirical support to a board's ability to effectively carry out the resource dependence role, but less to its ability to effectively perform the agency role. 
Distinct from most prior studies, our analysis places special emphasis on the importance of controlling for possible interrelations among alternative corporate governance (CG) mechanisms (non-executive directors, leverage, block, and institutional ownerships) and $Q$ using two-stage least squares (2SLS). The underlying notion is that because alternative CG mechanisms exist, the use of one mechanism (board size) may depend on the use of others (four alternative CG structures) to be effective. Of special interest, our $2 S L S$ results indicate that the coefficient on board size remains positive and significant in the presence of the other four CG mechanisms. The $2 S L S$ results reveal, however, that there is also a reverse link between board size and $Q$ (i.e., larger board size is not only associated with higher firm valuation, but successful SA firms also appear to be attractive to potential board members). We also find evidence of significant interrelations among the five CG mechanisms and $Q$, including a larger number of non-executive directors resulting in larger boards. This reinforces the need for future research to adequately consider possible alternative $\mathrm{CG}$ mechanisms in their analysis for robust findings.

Our evidence has important regulatory and policy implications. The King Committee and JSE Ltd have resisted from setting a maximum board size for SA firms. However, a general principle has been set that every board should consider whether or not its size makes it effective - leaving SA firms to decide their own optimal board size. Our findings appear to offer some support to the current policy. Since SA firms differ in size, industry and complexity of operations, it is reasonable to argue that adopting a 'one size fits all' instead of a flexible approach to board size may not necessarily improve performance. Our evidence also offers support to suggestions (see Guest, 2009) that the board size and firm valuation association may not merely vary by firm-level features, but also by country specific CG, institutional and legal differences.

While our findings are reliable and robust, some caveats are considered appropriate. Due to data limitations, we include a limited number of alternative CG mechanisms in our 2SLS analysis. As data coverage improves, future studies may need to include more mechanisms, such as data on the market for corporate control, in their analysis. Also, as our data covers a limited number of years, we could not apply data intensive alternative estimation techniques, such as granger causality test, which can enrich future research analysis, as more data becomes available in different contexts. 


\section{Acknowledgements}

The authors gratefully acknowledge the insightful suggestions by the Editor, Professor Malcolm Sawyer and an anonymous reviewer. We also acknowledge useful comments received at the School of Management and Business Seminar Presentation, Aberystwyth University, Wales, UK.

\section{Notes}

1. The Public Investment Corporation (PIC) is an investment company wholly owned by the South African government. It was established by the ruling African National Congress (ANC) as part of its neo-liberal economic policy of encouraging growth, employment and redistribution (GEAR) after the collapse of Apartheid in 1994 as a vehicle through which government can maintain ownership stakes in key SA corporations and industries. As at 31 March 2009, the PIC managed assets valued at R740bn (\$99bn) with at least a 5\% ownership stake in 40 of the largest 100 listed firms on the JSE by market capitalization. This easily makes the PIC the single largest institutional investor in SA (PIC Annual Report, 2009; Ntim and soobaroyen, 2013a, b).

2. The 1998 Employment Equity and 2003 Black Empowerment Acts formally require the membership of SA corporate boards to as much as possible reflect the gender and ethnic composition of the SA populace. An implication of this requirement is that the average SA corporate board should ideally have a non-white or black majority. Arguably, this makes board formation within the SA corporate setting unique, but relatively complex and problematic. This is because unlike companies in other Anglo-American countries, SA corporations must effectively pursue the contrasting objectives of appointing highly qualified and experienced board members and ensuring that membership of their boards reflects the ethnic and gender compositions of the SA citizenry.

3. Indeed, it is evident that the non-white board members of our sampled firms are dominated (about 40\%) either by former or active prominent members of the ruling ANC, with some of them occupying key positions, such as board and sub-committee chairpersons.

4. As financials and utilities are subject to different regulations and also differ in capital structure (Mangena and Chamisa, 2008; Ntim et al., 2012a, b), and following past studies (Yermack, 1996; Guest, 2009), we exclude 111 financials and utilities, leaving us with 291 companies to be sampled. The industrial breakdown of this initial sample is as follows: basic materials with 67 (23\%) firms; consumer goods with 36 (12\%) firms; consumer services with 62 (21\%) firms; healthcare with 7 (3\%) firms; industrials with 81 (28\%) firms; oil \& gas with 3 (1\%) firms; technology with 31 (11\%) firms; and telecoms with 4 (1\%) firms.

5. It takes time for board decisions to be reflected in firm value (Conyon and Peck, 1998). Hence, to avoid endogenous relationship between firm valuation and board size, we introduce a one year lag between board size and firm value such that a firm's value in any year $\left(Q_{t}\right)$ depends on the previous year's governance structure, similar to Conyon and Peck (1998). The sample also begins from 2002 for two reasons. Firstly, King II came into operation in 2002, and secondly, data coverage in the Perfect Information/DataStream on SA listed firms is very low until 2002. The sample ends in 2011 because it is the latest year for which data is available.

6. For 94 of the 122 remaining firms, two or more years' financial data and annual reports were not available in the DataStream/Perfect Information Database. For the other 28 firms, neither financial data nor annual reports were available. The industrial breakdown of our final 169 sample is as follows: basic materials with 33 (19\%) firms; consumer goods with 24 (14\%) firms; consumer services with 35 (21\%) firms; healthcare with $3(2 \%)$ firms; industrials with 51 (30\%) firms; oil \& gas with $1(1 \%)$ firms; technology with $19(11 \%)$ firms; and telecoms with $3(2 \%)$ firms. In addition, for lack of sufficient number of observations in three industries, namely health care, oil \& gas, and telecoms industries with three, one and three listed firms, respectively, observations from these industries were merged with the closest remaining five major industries. As a result, the three healthcare firms were added to the consumer services industry, the one oil \& gas firm was included in the basic materials industry, while the three telecoms companies were included in the technology industry. Our final 169 sample constituted $64 \%$ of the incomplete 263 sample, $58 \%$ of the possible 291 sample, and $42 \%$ of the total population of 402 listed firms.

7. To be highly certain, however, we further explore this potential problem by following Graham and Harvey (2001) and Beiner et al. (2006) and compare the characteristics of our final 169 sampled firms with all five years data available to those of the 263 out of the initial 291 with at least one year's data available rather than the complete five years, 94 of which were excluded from our final sample. Specifically, we test for equality in means and medians of all our financial variables, including capital expenditure, firm size, gearing, growth, leverage, return on assets, Tobin's Q and total share return, between our final balanced sample of 169 and the unbalanced sample of 263. If the two groups depict similar characteristics, then we can conclude that our final sample is representative of the underlying population. The results (which for brevity are not reported, but available upon request) indicate that there are no statistically significant differences in the mean or median values for all the variables. We interpret this observation as indicating that the characteristics of our final 169 sample are similar to the underlying population and that our findings are not likely to be impaired by survivorship bias.

8. To ensure that the residuals of a given firm may not be correlated across different years (time-series dependence) or firms (cross-sectional dependence) within our nine-year panel (Gujarati, 2003), and following Petersen (2009), we use the empirically robust Clustered Standard Errors technique to estimate the coefficients. Also, due to the gradual rather then rapid changes in the CG variables, we estimate separate regressions for each other firm-year starting from 2003, in addition to estimating a firm-level fixed effects model to minimise potential residual dependence.

9. To make sure the $2 S L S$ technique is appropriate, and following Beiner et al. (2006), we first conducted the popular DurbinWu-Hausman test (see Beiner et al., 2006: 267 for a detailed description of the procedure) to test for the endogeneity of the 
CG mechanisms and $Q$. Applied to equation 7, the Durbin-Wu-Hausman exogeneity test rejects the null hypothesis of no endogeneity at the $5 \%$ level. Thus, we conclude that $2 S L S$ technique is appropriate and that our OLS results may be spurious (i.e., biased and inconsistent).

10. The order-condition for identifying a system indicates that the number of exogenous variables excluded from any equation must be greater than or equal to the number of endogenous variables included minus one (Gujarati, 2003; Beiner et al., 2006). Our system of equations consists of 10 exogenous and 6 endogenous variables. Hence, at least 4 of our exogenous variables must be excluded from any single equation to identify the system. However, following prior research (Beiner et al., 2006; Larcker and Rusticus, 2010), equations (2) to (7) are separately developed based on theory, logic and data availability without excessive regard to satisfying the order-condition. As over-identification cannot jeopardise our system (Gujarati, 2003; Beiner et al., 2006), all our 6 equations are over-identified. Also, we conducted a Sargan test for instrument exogeneity, but could not be rejected (at least at the $10 \%$ level) for all 6 equations. We are, therefore, reasonably confident that our instruments are exogenous and our system is correctly specified.

\section{References}

Adams, R.B. and H. Mehran (2005), 'Corporate governance, Board Structure and its Determinants in the Banking Industry’. Working Paper, Federal Reserve Bank of New York.

Agrawal, A. and C.R. Knoeber (1996). 'Firm Performance and Mechanisms to Control Agency Problems between Managers and Shareholders', Journal of Financial and Quantitative Analysis, 31: 377-389.

Al-Najjar B. (2011), 'Empirical Modelling of Capital Structure: Jordanian Evidence. Journal of Emerging Market Finance, 10(1): 1-19.

Al-Najjar, B. (2013), 'The financial determinants of corporate cash holdings: Evidence from some emerging markets', International Business Review, 22(1), 77-88.

Barr, G., J. Gerson and B. Kanto (1995), Shareholders as Agents and Principals: The case for South Africa's Corporate Governance System', Journal of Applied Corporate Finance, 8: 18-31.

Beiner, S., W. Drobetz, F. Schmid and H. Zimmermann (2004), 'Is Board Size an Independent Corporate Governance Mechanism? Kyklos, 57: 327-356.

Beiner, S., W. Drobetz, M. Schmid and H. Zimmermann(2006), 'An Integrated Framework of Corporate Governance and Firm Valuation. European Financial Management, 12: 249-283.

Bevan, A.A. and J. Danbolt (2004), 'Testing for Inconsistencies in the Estimation of UK Capital Structure Determinants', Applied Financial Economic, 14: 55-66.

Bozec, R. (2005), 'Boards of Directors, Market Discipline and Firm Performance', Journal of Business

Finance and Accounting, 32: 1921-1960.

Chen, C.H. and B. Al-Najjar (2012). 'The Determinants of Board Size and Independence: Evidence from China', International Business Review, 21(5), 831-846.

Chen, C-J. and C-M.J. Yu (2012), 'Management Ownership, Diversification and Firm Performance: Evidence from an Emerging Market', International Business Review, 21(3): 518-534.

Cheng, S. (2008), 'Board Size and the Variability of Corporate Performance', Journal of Financial Economics. 87: 157-176.

Cheng, S., J.H. Evans and J. Nagarajan (2008), 'Board Size and Firm Performance: Moderating Effects of the Market for Corporate Control', Review of Quantitative Financial Accounting, 31: 121-145.

Chung, K. H. and S.W. Pruitt (1994), 'A Simple Approximation of Tobin's Q', Financial Management, 23: 70-74.

Conyon, M.J. and S.I. Peck (1998), 'Board Size and Corporate Performance: Evidence from European Countries', European Journal of Finance, 4: 291-304.

DeAngelo, L.E. (1981), 'Auditor Size and Auditor Quality', Journal of Accounting and Economics, 3, 183199.

Eisenberg, T., S. Sundregen and M. Wells (1998), 'Larger Board Size and Decreasing Firm Value in Small

Firms', Journal of Financial Economics, 48: 35-54.

Freeman, S. and S. Lindsay (2012), 'The Effect of Ethnic Diversity on Expatriate Managers in their Host Country', International Business Review, 21: 253-268.

Graham, J.R. and C.R. Harvey (2001), 'The Theory and Practice of Corporate Finance: Evidence from the Field', Journal of Financial Economics, 60: 187-243.

Guest, P.M. (2009), 'The Impact of Board Size on Firm Performance: Evidence from the UK', European Journal of Finance, 15: 385-404.

Gujarati, D.N. (2003). Basic econometrics. McGraw-Hill.

Henry, D. (2008), 'Corporate Governance Structure and the Valuation of Australian Firms: Is There Value in Ticking the Boxes. Journal of Business Finance and Accounting, 35: 912-942. 
Jensen, M.C. (1986), ‘Agency Costs of Free Cash Flow, Corporate Finance, and Takeovers', American Economic Review, 76: 323-329.

Jensen, M.C. (1993), 'The Modern Industrial Revolution, Exit, and the Failure of Internal Control Systems', Journal of Finance, 48: 831-80.

Jensen, M.C. and J.W. Meckling (1976), 'Theory of the Firm: Managerial Behaviour, Agency Costs and Ownership Structure', Journal of Financial Economics, 3: 305-360.

Kiel, G.C. and G.J. Nicholson (2003), 'Board Composition and Corporate Performance: How the Australian Experience Informs Contrasting Theories of Corporate Governance. Corporate Governance: An International Review, 11: 189-205.

King Committee (1994 \& 2002). King Reports on Corporate Governance for South Africa. Institute of Directors.

Kumar J. (2006), 'Corporate Governance and Dividends Payout in India', Journal of Emerging Market Finance, 5(1): 15-58.

Larcker, D.F. and T.O. Rusticus (2010), 'On the Use of Instrumental Variables in Accounting Research', Journal of Accounting and Economics, 49: 186-205.

Lasfer, M.D. (2004), 'On the Monitoring Role of the Board of Directors: The Case of the Adoption of Cadbury Recommendations in the UK', Advances in Financial Economics, 9: 287-326.

Lin, W-T. and Y. Liu (2012), 'Successor Characteristics, Organisational Slack, and Change in the Degree of Internationalisation. International Business Review, 21(1): 89-101.

Lipton, M. and J. Lorsch (1992), 'A Modest Proposal for Improved Corporate Governance', Business Lawyer, 48: 59-77.

Mak, Y.T. and K. Kusnadi (2005), 'Size Really Matters: Further Evidence on the Negative Relationship between Board Size and Firm Value. Pacific-Basin Finance Journal, 13: 301-318.

Malherbe, S. and N. Segal (2003) South Africa: After apartheid, in Corporate governance in development, the experiences of Brazil, Chile, India, and South Africa, (Eds) C. P. Oman, OECD: 248-251.

Mangena, M. and E. Chamisa (2008), 'Corporate Governance and Incidences of Listings Suspension by the JSE Securities Exchange of South Africa: An Empirical Analysis. International Journal of Accounting, 43: 28-44.

Mangena, M., V. Tauringana and E. Chamisa (2012), 'Corporate Boards, Ownership Structure and Firm Performance in an Environment of Severe Political and Economic Uncertainty. British Journal of Management, 23(1), 23-41.

Mukherjee P. and Roy M. (2011), 'The Nature and Determinants of Investments by Institutional Investors in the Indian Stock Market', Journal of Emerging Market Finance, 10(3): 253-283.

Murray, G. (2000), 'Black Empowerment in South Africa: "Patriotic capitalism” or Corporate Black Wash?' Critical Sociology, 26: 182-204.

Ntim, C.G., Lindop, S., Osei, K.A., and Thomas, D.A. (2014), 'Executive Director Pay, Corporate Governance and Performance: A Simultaneous Equation Approach', Managerial and Decision Economics, in press, (doi:10.1002/mde.2653).

Ntim, C.G. (2014), 'Board Diversity and Organizational Valuation: Unravelling the Effects of Ethnicity and Gender', Journal of Management and Governance, In press, (doi: 10.1007/s10997-013-9283-4).

Ntim, C.G. and Soobaroyen, T. (2013a), 'Black economic empowerment disclosures by South African listed corporations: Influence of ownership and board characteristics', Journal of Business Ethics, 116(1): 121138.

Ntim, C. G. and Soobaroyen, T. (2013b), 'Corporate governance and performance in socially responsible corporations: new empirical insights from a neo-institutional framework', Corporate Governance: An International Review, 21(5): 468-494.

Ntim, C.G., Opong, K. K., J. Danbolt and D.A. Thomas (2012a). 'Voluntary Corporate Governance Disclosures by Post-Apartheid South African Corporations', Journal of Applied Accounting Research, 13(2), 122-144.

Ntim, C.G., Lindop, S., and Thomas, D.A. (2013). 'Corporate Governance and Risk Reporting in South Africa: A Study of Corporate Risk Disclosures in the Pre- and Post-2007/2008 Global Financial Crisis Period', International Review of Financial Analysis, 30: 363-383.

Ntim, C.G., K.K. Opong, and J. Danbolt (2012b). The Relative Value Relevance of Shareholder versus Stakeholder Corporate Governance Disclosure Policy Reforms in South Africa', Corporate Governance: An International Review, 20(1): 84-105.

Okeahalam, C.C. (2004), 'Corporate Governance and Disclosure in Africa: Issues and Challenges', Journal of Financial Regulation and Compliance, 12: 359-370. 
Pant, M. and Pattanayak, M. (2010), 'Corporate Governance, Competition and Firm Performance: Evidence from India', Journal of Emerging Market Finance, 9(3): 347-381.

Petersen, M.A. (2009), 'Estimating Standard Errors in Finance Panel Data Sets: Comparing Approaches', Review of Financial Studies, 22: 435-480.

Pfeffer, J. (1973), 'Size, Composition, and Function of Hospital Boards of Directors: A Study of

Organization-Environmental Linkage', Administrative Science Quarterly, 18: 349-364.

Rivas, J.L. (2012), 'Diversity \& Internationalization: The case of Boards and TMT's', International Business Review, 21: 1-12.

Sanda, A., A.S. Mikailu and T. Garba (2010), 'Corporate Governance Mechanisms and Firm Financial

Performance in Nigeria', Afro-Asian Journal of Finance and Accounting, 2: 22-39.

Siougle, G. (2007), 'Earnings Forecasts Disclosed in SEO Prospectuses: Evidence from an Emerging Market', Journal of Emerging Market Finance, 6 (3): 249-267.

Vefeas, N. (1999), 'Board Meeting Frequency and Firm Performance', Journal of Financial Economics, 53 : 113-142.

Walker Review (2009), 'A Review of Corporate Governance in UK Banks and Other Financial Industry Entities', HM Treasury.

Yermack, D. (1996), 'Higher Market Valuation of Companies with a Small Board of Directors', Journal of Financial Economics, 40: 185-211.

Table 1 Summary of measures and variables

\begin{tabular}{|c|c|}
\hline \multicolumn{2}{|c|}{ Market and CG (endogenous) variables } \\
\hline $\mathrm{ROA}$ & Percentage of operating profit (wc01250) to total assets (wc02999). \\
\hline TSR & $\begin{array}{l}\text { Natural log of continuously compounded total shareholder return made up of capital gain } \\
\text { and dividend yield. }\end{array}$ \\
\hline Q & $\begin{array}{l}\text { Ratio of total assets (wc02999) minus book value of equity (wc03501+wc03451) plus } \\
\text { market value (mv) of equity to total assets (wc02999). }\end{array}$ \\
\hline BSIZE & Natural log of the total number of directors on the board of a company. \\
\hline NEDs & Percentage of non-executive directors to total number of directors on a board. \\
\hline LEV & Percentage of total debt (wc03255) to total assets (wc02999). \\
\hline BLKOWN & $\begin{array}{l}\text { Percentage of common shares held by shareholders with at least } 5 \% \text { of the total company } \\
\text { shareholdings. }\end{array}$ \\
\hline INSOWN & Percentage of common shares held by institutional shareholders. \\
\hline \multicolumn{2}{|c|}{ Control (exogenous) variables } \\
\hline GOVOWN & $\begin{array}{l}\text { A dummy variable that takes the value of } 1 \text { if government ownership of ordinary shares is at } \\
\text { least } 5 \% \text {, otherwise } 0 .\end{array}$ \\
\hline GEAR & Percentage of total debt to market value of equity. \\
\hline LNTA & Natural log of total assets (wc02999). \\
\hline BIG4 & $\begin{array}{l}\text { 1, if a firm is audited by a big four audit firm (PricewaterhouseCoopers, Deloitte \& } \\
\text { Touche, Ernst \& Young, and KPMG), } 0 \text { otherwise. }\end{array}$ \\
\hline CGCOM & 1, if a firm is listed on a foreign stock market, 0 otherwise. \\
\hline CROSLIST & $\begin{array}{l}\text { A dummy variable that takes the value of } 1 \text { if a firm is cross-listed to a foreign stock market, } \\
0 \text { otherwise. }\end{array}$ \\
\hline CAPEX & Percentage of total capital expenditure (wc04601) to total assets (wc02999). \\
\hline GROWTH & $\begin{array}{l}\text { Percentage of current year's sales (wc01001) minus previous year's sales scaled by previous } \\
\text { year's sales. }\end{array}$ \\
\hline INDUST & $\begin{array}{l}\text { Dummies for each of the five main industries: basic material + oil \& gas; consumer goods; } \\
\text { consumer services + health care; industrials; technology + telecommunications firms. }\end{array}$ \\
\hline YD & Dummies for each of the five years from 2003 to 2011 inclusive. \\
\hline CGCOM & 1 , if a firm has set up a corporate governance committee, 0 otherwise. \\
\hline
\end{tabular}

Notes: The codes in parentheses refer to Datastream codes for the respective accounting and market variables used in the analysis. 
Table 2

Descriptive statistics of all variables for all $(1,521)$ firm years

\begin{tabular}{|c|c|c|c|c|c|}
\hline Variable & Mean & Median & Std. dev. & Maximum & Minimum \\
\hline \multicolumn{6}{|c|}{ Firm Valuation/Corporate governance (endogenous) variables } \\
\hline $\mathrm{Q}$ & 1.56 & 1.34 & 0.67 & 3.60 & 0.72 \\
\hline $\operatorname{ROA}(\%)$ & 10.74 & 11.86 & 13.95 & 37.85 & -19.34 \\
\hline TSR $(\%)$ & 28.36 & 25.13 & 88.67 & 236.42 & -48.29 \\
\hline BLKOWN (\%) & 62.38 & 64.61 & 18.48 & 91.72 & 10.21 \\
\hline BSIZE & 9.75 & 10.00 & 3.67 & 18.00 & 4.00 \\
\hline INSOWN (\%) & 74.21 & 82.13 & 22.86 & 97.69 & 9.42 \\
\hline $\operatorname{LEV}(\%)$ & 17.66 & 16.30 & 13.64 & 55.83 & 5.13 \\
\hline NEDs $(\%)$ & 56.73 & 57.69 & 15.41 & 84.25 & 17.36 \\
\hline \multicolumn{6}{|c|}{ Control (exogenous) variables } \\
\hline BIG4(\%) & 73.25 & 100.00 & 44.28 & 100.00 & 0.00 \\
\hline CAPEX (\%) & 12.83 & 8.22 & 15.31 & 66.43 & 7.28 \\
\hline CGCOM (\%) & 32.21 & 0.00 & 47.08 & 100.00 & 0.00 \\
\hline CROSLIST $(\%)$ & 21.66 & 0.00 & 41.22 & 100.00 & 0.00 \\
\hline GEAR $(\%)$ & 32.14 & 17.62 & 30.81 & 78.31 & 1.36 \\
\hline GOVOWN (\%) & 38.31 & 0.00 & 49.25 & 100.00 & 0.00 \\
\hline GROWTH (\%) & 12.27 & 13.91 & 26.35 & 89.47 & -44.21 \\
\hline LNTA & 5.86 & 6.02 & 0.48 & 7.83 & 4.24 \\
\hline
\end{tabular}


Table 3

Pearson and Spearman correlation matrices of all variables for all (1,521) firm years

\begin{tabular}{|c|c|c|c|c|c|c|c|c|c|c|c|c|c|c|}
\hline Variable & Q & NEDs & GOVOWN & BSIZE & BLKOWN & INSOWN & LEV & GROWTH & CAPEX & LNTA & GEAR & BIG4 & CROSLIST & CGCOM \\
\hline $\bar{Q}$ & & $.147^{* * *}$ & $.205^{* * *}$ & $.173^{* * * *}$ & -.028 & $.195^{* * * *}$ & $-.132^{* * * *}$ & $.089^{* * *}$ & $-.394^{* * * *}$ & $.114^{* * *}$ & $-.398^{* * * *}$ & $.126^{* * * *}$ & $.174^{* * * *}$ & $.184^{* * * *}$ \\
\hline NEDs & $.134^{* * * *}$ & & $.226^{* * * *}$ & $.224^{* * *}$ & -.027 & $.152^{* * * *}$ & .048 & $-.118^{* * * *}$ & -.019 & $.328^{* * * *}$ & -.020 & $.257^{* * * *}$ & $.228^{* * * *}$ & $.197^{* * * *}$ \\
\hline GOVOWN & $.175^{* * * *}$ & $.228^{* * * *}$ & & $.389^{* * *}$ & $-.179^{* * * *}$ & $.216^{* * * *}$ & $.080^{*}$ & $.104^{* *}$ & -.032 & $.445^{* * *}$ & -.035 & $.298^{* * * *}$ & $.375^{* * * *}$ & $.366^{* * * *}$ \\
\hline BSIZE & $.121^{* * * *}$ & $.226^{* * * *}$ & $.377^{* * * *}$ & & $-.098^{* *}$ & $.298^{* * *}$ & $.166^{* * * *}$ & $.095^{* *}$ & .065 & $.520^{* * * *}$ & $.080^{*}$ & $.387^{* * * *}$ & $.379^{* * * *}$ & $.309^{* * * *}$ \\
\hline BLKOWN & -.038 & -.017 & $-.159^{* * * *}$ & -.067 & & $.410^{* * * *}$ & .037 & .022 & .055 & $-.138^{* * *}$ & .024 & -.012 & -.031 & $-.111^{* * * *}$ \\
\hline INSOWN & $.149^{* * * *}$ & $.149^{\text {**** }}$ & $.220^{* * * *}$ & $.278^{* * * *}$ & $.370^{* * * *}$ & & .054 & .069 & -.069 & $.276^{* * * *}$ & -.046 & $.109^{* * * *}$ & $.256^{* * * *}$ & $.244^{* * * *}$ \\
\hline LEV & $-.117^{* * * *}$ & $-.068^{*}$ & .003 & $.129^{* * * *}$ & $.095^{* * *}$ & $.097^{* *}$ & & -.065 & $.328^{* * * *}$ & $.194^{* * * *}$ & $.588^{* * * *}$ & .025 & $.086^{* *}$ & $.158^{* * * *}$ \\
\hline GROWTH & $.079^{*}$ & $-.109^{* * * *}$ & $.079^{*}$ & $.090^{* *}$ & .028 & .053 & $-.085^{* *}$ & & -.044 & $.128^{* * * *}$ & $-.098^{* *}$ & .012 & -.018 & .026 \\
\hline CAPEX & $-.314^{* * * *}$ & -.056 & $-.113^{* * * *}$ & $-.078^{*}$ & .049 & $-.082^{* *}$ & $.320^{* * * * *}$ & -.058 & & $.089^{* *}$ & $.412^{* * *}$ & $.075^{*}$ & .050 & -.008 \\
\hline LNTA & $.078^{*}$ & $.346^{\text {***** }}$ & $.416^{* * * *}$ & $.497^{* * * *}$ & $-.182^{* * * *}$ & $.256^{* * * *}$ & $.129^{* * * * *}$ & $.123^{* * * *}$ & -.036 & & $.103^{* *}$ & $.430^{* * * *}$ & $.428^{* * * *}$ & $.398^{* * * *}$ \\
\hline GEAR & $-.296^{* * *}$ & $.297^{* * * *}$ & $-.147^{* * * *}$ & $-.075^{*}$ & .045 & $-.078^{*}$ & $.565^{* * * *}$ & $-.068^{*}$ & $.392^{* * *}$ & -.042 & & -.036 & -.045 & .064 \\
\hline BIG4 & $.137^{* * * *}$ & $.249^{* * * *}$ & $.295^{* * * *}$ & $.368^{* * * *}$ & -.059 & $.109^{* *}$ & -.034 & .020 & -.014 & $.423^{* * *}$ & $-.075^{*}$ & & $.248^{* * *}$ & $.277^{\text {**** }}$ \\
\hline CROSLIST & $.168^{* * * *}$ & $.225^{* * * *}$ & $.371^{* * * *}$ & $.369^{* * * *}$ & -.041 & $.177^{* * * *}$ & .038 & -.010 & $-.104^{* *}$ & $.418^{* * * *}$ & $-.102^{* *}$ & $.248^{* * * *}$ & & $.439^{* * * *}$ \\
\hline CGCOM & $.165^{* * * *}$ & $.204^{* * * *}$ & $.364^{* * * *}$ & $.310^{* * * *}$ & $-.108^{* *}$ & $.239^{* * * *}$ & $.127^{* * * * *}$ & .044 & $-.088^{* * *}$ & $.370^{\text {**** }}$ & $-.135^{* * *}$ & $.277^{* * * *}$ & $.439^{\text {**** }}$ & \\
\hline
\end{tabular}

Notes: The bottom left half of the table contains Pearson's parametric correlation coefficients, while the upper right half of the table shows Spearman's non-parametric correlation coefficients. $* * *, * *$ and * indicate that correlation is significant at the $1 \%, 5 \%$ and $10 \%$ level, respectively. Variables are defined as follows: Tobin's Q $(Q)$, percentage of non-executive directors (NEDs), government ownership $(G O V O W N)$, board size $(B S I Z E)$, block ownership $(B L K O W N)$, institutional ownership (INSOWN), leverage (LEV), growth $(G R O W T H)$, capital expenditure $(C A P E X)$, firm size $(L N T A)$, gearing $(G E A R)$, audit firm size (BIG4), cross-listing (CROSLIST), and the presence of a corporate governance committee (CGCOM). Table 1 fully defines all the variables used. 
Table 4

OLS regression results of Tobin's $\mathrm{Q}(\mathrm{Q})$ on board size and the control variables

\begin{tabular}{|c|c|c|c|c|c|c|c|c|}
\hline & $\begin{array}{l}\text { Exp. } \\
\text { Sign }\end{array}$ & All firm years & All firm years & 2003 & 2005 & 2007 & 2009 & 2011 \\
\hline $\begin{array}{l}\text { Adjusted } R^{2} \\
\text { Standard Error } \\
\text { Durbin-Watson } \\
F \text {-Value } \\
\text { Sample Size }(N)\end{array}$ & & $\begin{array}{l}.028 \\
.684 \\
1.840 \\
6.908^{* * *} \\
1,521 \\
\end{array}$ & $\begin{array}{c}.412 \\
.423 \\
2.930 \\
10.756^{* * *} \\
1,521 \\
\end{array}$ & $\begin{array}{c}.214 \\
.510 \\
2.145 \\
4.771^{* * *} \\
169 \\
\end{array}$ & $\begin{array}{c}.309 \\
.467 \\
2.318 \\
8.675^{* * *} \\
169 \\
\end{array}$ & $\begin{array}{c}.240 \\
.498 \\
2.183 \\
6.794^{* * *} \\
169 \\
\end{array}$ & $\begin{array}{c}.171 \\
.584 \\
2.100 \\
4.521^{* * * *} \\
169 \\
\end{array}$ & $\begin{array}{c}.283 \\
.489 \\
2.215 \\
7.363^{* * *} \\
169 \\
\end{array}$ \\
\hline $\begin{array}{l}\text { Constant } \\
\text { BSIZE } \\
\text { GOVOWN } \\
\text { BIG4 } \\
\text { CAPEX } \\
\text { CROSLIST } \\
\text { LNTA } \\
\text { GEAR } \\
\text { GROWTH } \\
\text { Basic materials } \\
\text { Consumer services } \\
\text { Industrials } \\
\text { Technology } \\
\text { Year 2005 } \\
\text { Year 2007 } \\
\text { Year 2009 } \\
\text { Year 2011 }\end{array}$ & $\begin{array}{c}+ \\
+ \\
+ \\
-/+ \\
+ \\
-/+ \\
-/+ \\
-/+\end{array}$ & $\begin{array}{c}.518(.000)^{* * * *} \\
.104(.000)^{* * *} \\
- \\
- \\
- \\
- \\
- \\
- \\
- \\
- \\
- \\
- \\
- \\
- \\
- \\
- \\
-\end{array}$ & $\begin{array}{l}.325(.009)^{* * *} \\
.081(.006)^{* * *} \\
.176(.021)^{* * *} \\
.112(.048)^{* *} \\
-.013(.432)^{* *} \\
.105(.026)^{* *} \\
-.069(.045)^{* *} \\
-.018(.510) \\
.039(.192) \\
.054(.395) \\
.214(.000)^{* * *} \\
.064(.258) \\
.083(.234) \\
.113(.033)^{* *} \\
.126(.042)^{* *} \\
.228(.000)^{* * *} \\
.243(.000)^{* * *}\end{array}$ & $\begin{array}{c}.286(.000)^{* * *} \\
.024(.051)^{*} \\
.122(.050)^{* *} \\
.110(.058)^{*} \\
-.056(.397) \\
.172(.049)^{* *} \\
-.095(.064)^{*} \\
-.015(.321)^{* *} \\
.106(.093)^{*} \\
.085(.401) \\
.276(.038)^{* *} \\
.094(.525) \\
.309(.000)^{* * *} \\
- \\
- \\
-\end{array}$ & $\begin{array}{c}.350(.000)^{* * *} \\
.096(.000)^{* * *} \\
.104(.056)^{*} \\
.189(.041)^{* *} \\
-.018(.429) \\
.312(.000)^{* * *} \\
-.195(.000)^{* * *} \\
-.074(.265) \\
.023(.480) \\
.029(.531) \\
.292(.024)^{* *} \\
.088(.527) \\
.093(.320) \\
- \\
- \\
- \\
-\end{array}$ & $\begin{array}{c}.287(.000)^{* * *} \\
.044(.025)^{* *} \\
.100(.064)^{*} \\
.197(.028)^{* *} \\
-.022(.401) \\
.236(.019)^{* *} \\
-.120(.033)^{* *} \\
-.031(.384) \\
.029(.396) \\
.052(.341) \\
.313(.000)^{* * *} \\
.068(.379) \\
.105(.226) \\
- \\
- \\
- \\
-\end{array}$ & $\begin{array}{c}.218(.000)^{* * *} \\
.027(.053)^{*} \\
.095(.087)^{*} \\
.076(.089)^{*} \\
-.012(.471) \\
.086(.064)^{*} \\
-.135(.047)^{* *} \\
-.012(.450) \\
.055(.463) \\
.060(.339) \\
.228(.085)^{*} \\
.087(.194) \\
.114(.171) \\
- \\
- \\
- \\
-\end{array}$ & $\begin{array}{c}.325(.000)^{* * *} \\
.038(.030)^{* *} \\
.114(.028)^{* *} \\
.229(.000)^{* * *} \\
-.025(.248) \\
.210(.043)^{* *} \\
-.078(.089)^{*} \\
-.011(.475) \\
.110(.087)^{*} \\
.073(.269) \\
.291(.050)^{* *} \\
.095(.174) \\
.128(.159) \\
- \\
- \\
-\end{array}$ \\
\hline
\end{tabular}

Notes: Coefficients are in front of parenthesis containing $p$-values. ***,** and * denote test statistic significance at the $1 \%, 5 \%$ and $10 \%$ level, respectively. Following Petersen (2009), coefficients are estimated by using the robust clustered standard errors technique. The consumer goods industry and year 2003 are captured by the constant term in the pooled analysis, and for brevity we report coefficients for every other year beginning from 2005. Variables are defined as follows: Tobin's Q $(Q)$, board size $(B S I Z E)$, government ownership $(G O V O W N)$, audit firm size $(B I G 4)$, capital expenditure (CAPEX), cross-listing (CROSLIST), firm size (LNTA), gearing $(G E A R)$ and growth $(G R O W T H)$. Table 1 fully defines all the variables used. 
Table 5

Regression results from a two-stage least squares estimation of equations (2) to (7)

\begin{tabular}{|c|c|c|c|c|c|c|c|}
\hline $\begin{array}{l}\text { Dependent variable } \\
\text { (Equation) }\end{array}$ & $\begin{array}{l}\text { Exp. } \\
\text { Sign }\end{array}$ & $\begin{array}{l}\text { BSIZE } \\
(2)\end{array}$ & $\begin{array}{l}\text { NEDs } \\
(3)\end{array}$ & $\begin{array}{c}\text { LEV } \\
(4)\end{array}$ & $\begin{array}{c}\text { BLKOWN } \\
(5)\end{array}$ & $\begin{array}{l}\text { INSOWN } \\
(6)\end{array}$ & $\begin{array}{c}Q \\
(7)\end{array}$ \\
\hline Adjusted $R^{2}$ & & .396 & .183 & .134 & .236 & .291 & .469 \\
\hline Standard Error & & .439 & .558 & .597 & .498 & .476 & .419 \\
\hline Durbin-Watson & & 2.802 & 2.130 & 1.963 & 2.120 & 2.325 & 2.975 \\
\hline$F$-Value & & $10.612^{* * *}$ & $4.654^{* * *}$ & $4.508^{* * *}$ & $6.780^{* * *}$ & $7.538^{* * *}$ & $11.127^{* * *}$ \\
\hline Sample Size $(N)$ & & 1,521 & 1,521 & 1,521 & 1,521 & 1,521 & 1,521 \\
\hline Constant & & $.142(.196)$ & $.985(.320)$ & $-.630(.138)$ & $.729(.000)^{* * *}$ & $-.972(.140)$ & $.295(.064)^{*}$ \\
\hline BSIZE & + & - & $.403(.000)^{* * *}$ & $.396(.085)^{*}$ & $-.841(.543)$ & $.964(.000)^{* * *}$ & $.056(.028)^{* *}$ \\
\hline NEDs & + & $.044(.000)^{* * *}$ & - & $.057(.231)$ & $.049(.396)$ & $.109(.123)$ & $.032(.095)^{*}$ \\
\hline LEV & $-/+$ & $.028(.315)$ & $.091(.305)$ & - & $.174(.023)^{* * *}$ & $.027(.874)$ & $-.078(.069)^{*}$ \\
\hline BLKOWN & $-/+$ & $-.039(.620)$ & $-.056(.470)$ & $.061(.084)^{*}$ & - & $.495(.000)^{* * *}$ & $-.052(.351)$ \\
\hline INSOWN & + & $.080(.000)^{* * *}$ & $.074(.125)$ & $.025(.637)$ & $.386(.000)^{* * * *}$ & - & $.085(.054)^{*}$ \\
\hline$Q_{t}$ & $-/+$ & $.046(.070)^{*}$ & $.482(.093)^{*}$ & $-.394(.416)$ & $.342(.630)$ & $.412(.483)$ & - \\
\hline GOVOWN & + & $.153(.058)^{*}$ & $.613(.018)^{* *}$ & - & - & $.540(.046)^{* *}$ & $.109(.058)^{*}$ \\
\hline CGCOM & + & $.094(.076)^{*}$ & $.132(.495)$ & - & - & $.196(.034)^{* *}$ & - \\
\hline BIG4 & + & $.120(.000)^{* * *}$ & $.420(.063)^{*}$ & - & - & - & $.074(.040)^{* *}$ \\
\hline CAPEX & + & $-.076(.020)^{* *}$ & $-.084(.138)$ & $.242(.000)^{* * *}$ & $.238(.024)^{* *}$ & $-.087(.425)$ & $.028(.453)$ \\
\hline CROSLIST & $-/+$ & $.059(.027)^{* *}$ & $.470(.069)^{*}$ & - & - & - & $.112(.019)^{* *}$ \\
\hline LNTA & + & $.329(.000)^{* * *}$ & $.953(.000)^{* * *}$ & $.726(.045)^{* * *}$ & $-.815(.000)^{* * *}$ & $.290(.031)^{* *}$ & $-.086(.074)^{*}$ \\
\hline GEAR & $-/+$ & $.043(.265)$ & $.025(.648)$ & - & $-.076(.151)$ & - & $.016(.450)$ \\
\hline GROWTH & $-/+$ & $.084(.512)$ & $-.104(.009)^{* * * *}$ & $-.048(.129)$ & $.082(.197)$ & $-.073(.426)$ & $.024(.197)$ \\
\hline Basic materials & $-/+$ & $-.148(.000)^{* * *}$ & $-.671(.580)$ & $.743(.036)^{* *}$ & $.349(.046)^{* *}$ & $.342(.390)$ & $.058(.375)$ \\
\hline Consumer services & & $-.062(.271)$ & $.396(.163)$ & $-.528(.452)$ & $-.357(.019)^{* *}$ & $.923(.000)^{* * *}$ & $.316(.000)^{* * *}$ \\
\hline Industrials & & $.173(.080)^{*}$ & $-.142(.864)$ & $.897(.063)^{*}$ & $-.280(.216)$ & $.464(.628)$ & $.081(.226)$ \\
\hline Technology & & $-.101(.437)$ & $.981(.436)$ & $.472(.030)^{* *}$ & $-.292(.361)$ & $.780(.040)^{* *}$ & $.065(.264)$ \\
\hline Year 2005 & & $.018(.720)$ & $.312(.190)$ & $-.641(.610)$ & $.346(.050)^{* *}$ & $-.728(.463)$ & $.230(.031)^{* *}$ \\
\hline Year 2007 & & $.092(.565)$ & $.506(.037)^{* *}$ & $-.128(.743)$ & $.124(.063)^{*}$ & $-.675(.719)$ & $.359(.018)^{* *}$ \\
\hline Year 2009 & & $-.068(.632)$ & $.635(.023)^{* *}$ & $.306(.091)^{*}$ & $.175(.091)^{*}$ & $.863(.008)^{* * *}$ & $.420(.000)^{* * *}$ \\
\hline Year 2011 & & $.040(.711)$ & $.740(.028)^{* *}$ & $.298(.094)^{*}$ & $.157(.062)^{*}$ & $.894(.000)^{* * *}$ & $.457(.000)^{* * * *}$ \\
\hline
\end{tabular}

Notes: Coefficients are in front of parenthesis containing $p$-values. ***, ** and * denote test statistic significance at the $1 \%, 5 \%$ and $10 \%$ level, respectively. Following Petersen (2009), coefficients are estimated by using the robust clustered standard errors technique. The consumer goods industry and year 2003 are captured by the constant term in the pooled analysis, and brevity, we report coefficient of every other year beginning from 2005. Equations (2) to (6) examine the interrelations among the $5 \mathrm{CG}$ mechanisms, while equation (7) investigates the association between firm value $(Q)$ and the CG mechanisms. Variables are defined as follows: Tobin's Q $(Q)$, board size $(B S I Z E)$, percentage of non-executive directors $(N E D s)$, leverage $(L E V)$, block ownership $(B L K O W N)$, institutional ownership (INSOWN), government ownership (GOVOWN), the presence of a corporate governance committee (CGCOM), audit firm size (BIG4), capital expenditure (CAPEX), cross-listing (CROSLIST), firm size (LNTA), gearing $(G E A R)$ and growth $(G R O W T H)$. Table 1 fully defines all the variables used. 
Table 6

Regression results based on alternative firm valuation proxies and the estimation of a fixed-effects model

\begin{tabular}{|c|c|c|c|c|c|c|}
\hline \multirow{3}{*}{$\begin{array}{l}\text { Dependent Variable } \\
\text { Adjusted } R^{2}\end{array}$} & & \multicolumn{4}{|c|}{ Alternative firm value proxies } & \multirow{2}{*}{$\begin{array}{c}\text { Fixed-effects model } \\
\text { Tobin's Q } \\
(Q)\end{array}$} \\
\hline & $\begin{array}{l}\text { Exp. } \\
\text { Sign }\end{array}$ & \multicolumn{2}{|c|}{$\begin{array}{l}\text { Total share returns } \\
(T S R)\end{array}$} & \multicolumn{2}{|c|}{$\begin{array}{c}\text { Return on assets } \\
(R O A)\end{array}$} & \\
\hline & & .023 & .308 & .037 & .190 & .467 \\
\hline Standard error & & .680 & .457 & .635 & .479 & .435 \\
\hline Durbin-Watson & & 1.818 & 2.329 & 1.923 & 2.143 & 2.980 \\
\hline$F$-value & & $6.540^{* * *}$ & $8.790^{* * *}$ & $6.590^{* * *}$ & $5.648^{*}$ & $7.312^{* * *}$ \\
\hline Sample size $(N)$ & & 1,521 & 1,521 & 1,521 & 1,521 & 1,521 \\
\hline Constant & & $.692(.758)$ & $.264(.185)$ & $-.048(.274)$ & $-.067(.435)$ & $.494(.000)^{* * *}$ \\
\hline BSIZE & + & $.136(.000)^{* * *}$ & $.115(.026)^{* *}$ & $.095(.000)^{* * * *}$ & $.143(.000)^{* * *}$ & $.112(.000)^{* * *}$ \\
\hline GOVOWN & + & - & $.110(.063)^{*}$ & - & $.135(.041)^{* *}$ & $.104(.075)^{*}$ \\
\hline BIG4 & + & - & $.214(.059)^{*}$ & - & $-.109(.056)^{*}$ & $.296(.000)^{* * *}$ \\
\hline CAPEX & $-/+$ & - & $-.290(.046)^{* *}$ & - & $-.074(.595)$ & $-.053(.415)$ \\
\hline CROSLIST & + & - & $.324(.073)^{*}$ & - & $.128(.023)^{* *}$ & $.186(.074)^{*}$ \\
\hline LNTA & + & - & $-.185(.091)^{*}$ & - & $.254(.000)^{* * *}$ & $-.190(.023)^{* *}$ \\
\hline GEAR & $-/+$ & - & $-.054(.286)$ & - & $-.036(.160)$ & $-.046(.470)$ \\
\hline GROWTH & $-/+$ & - & $.285(.000)^{* * *}$ & - & $.029(.524)$ & $.085(.311)$ \\
\hline Basic materials & + & - & $-.375(.803)$ & - & $-.065(.038)^{* *}$ & $.248(.463)$ \\
\hline Consumer services & + & - & $.740(.056)^{*}$ & - & $.054(.297)$ & $.352(.501)$ \\
\hline Industrials & + & - & $.512(.320)$ & - & $.085(.703)$ & $.197(.604)$ \\
\hline Technology & & - & $-.421(.164)$ & - & $.092(.284)$ & $.320(.461)$ \\
\hline Year 2005 & & - & $.941(.110)$ & - & $-.058(.310)$ & $.586(.000)^{* * *}$ \\
\hline Year 2007 & & - & $.850(.196)$ & - & $.103(.135)$ & $.649(.000)^{* * *}$ \\
\hline Year 2009 & & - & $.876(.075)^{*}$ & - & $.096(.274)$ & $.712(.000)^{* * *}$ \\
\hline Year 2011 & & - & $.950(.000)^{* * *}$ & - & $.118(.395)$ & $.904(.000)^{* * *}$ \\
\hline
\end{tabular}

Notes: Coefficients are in front of parenthesis containing $p$-values. ***,**and * denote test statistic significance at the $1 \%, 5 \%$ and $10 \%$ level, respectively. Following Petersen (2009), coefficients are estimated by using the robust clustered standard errors technique. The consumer goods industry and year 2003 are captured by the constant term in the pooled analysis, and for brevity, we report coefficients for every other year dummy beginning from 2005. Variables are defined as follows: Tobin's Q $(Q)$, board size (BSIZE), government ownership (GOVOWN), audit firm size (BIG4), capital expenditure (CAPEX), cross-listing (CROSLIST), firm size (LNTA), gearing (GEAR) and growth (GROWTH). Table 1 fully defines all the variables used. 